\title{
Valproic acid activity in androgen-sensitive and -insensitive human prostate cancer cells
}

\author{
FORTUNATA IACOPINO ${ }^{1}$, RAFFAELLA URBANO ${ }^{1}$, GRAZIA GRAZIANI ${ }^{3}$, \\ ALESSIA MUZI ${ }^{3}$, PIERLUIGI NAVARRA ${ }^{2}$ and GIGLIOLA SICA ${ }^{1}$ \\ Institutes of ${ }^{1}$ Histology and Embryology and ${ }^{2}$ Pharmacology, Faculty of Medicine, Catholic \\ University of the Sacred Heart, Largo Francesco Vito 1, 00168 Rome; ${ }^{3}$ Pharmacology and Medical \\ Oncology Section, Department of Neuroscience, University of Rome 'Tor Vergata', 00100 Rome, Italy
}

Received January 9, 2008; Accepted February 22, 2008

\begin{abstract}
Histone deacetylase (HDAC) inhibitors are currently undergoing clinical trials in cancer patients on the basis of their effect on proliferation, differentiation and apoptosis demonstrated in vitro. The goal of this study was to assess the effects of an HDAC inhibitor, valproic acid (VA), on proliferation, androgen-sensitivity, androgen receptor levels and E-cadherin (E-cad) expression in human prostate cancer cells. The effects of VA were evaluated in androgen-sensitive, LNCaP and -insensitive PC-3 human prostate cancer cell lines. Proliferation was assayed by cell counts and protein expression by Western blot analysis. Morphological changes were analysed under an inverted phase contrast microscope. High VA concentrations (1-25 mM) induced a very strong reduction in cell numbers ( $\sim 90 \%$ with respect to control) of the two cell lines due to drug cytotoxicity. A low concentration (0.45 mM VA) slightly reduced (14\%) LNCaP cell proliferation and abolished the response to androgen. In the PC-3 cells, the same concentration of VA had a more pronounced (40\%) inhibitory effect and induced a response to dihydrotestosterone in terms of an enhancement in cell growth. These events were associated with morphological changes, an absence of cytotoxicity, an increase in androgen receptor levels, and, in PC-3 cells, an enhancement in E-cad expression which may be ascribed to VA differentiative action. Our findings, obtained with a VA dose $(0.45 \mathrm{mM})$, which is consistent with plasma concentrations reached under oral administration of therapeutical doses in patients treated for different diseases, suggest that VA might have clinical value in prostate cancer therapy in androgen-sensitive and insensitive tumors.
\end{abstract}

Correspondence to: Professor Gigliola Sica, Institute of Histology and Embryology, Faculty of Medicine, Catholic University of the Sacred Heart, Largo Francesco Vito 1, 00168 Rome, Italy

E-mail: gigliola@rm.unicatt.it,ibiis@rm.unicatt.it

Key words: prostate cancer cells, valproic acid, hormone-sensitivity, androgen receptor, differentiation

\section{Introduction}

Histone deacetylase (HDAC) inhibitors are currently being developed as a new class of anti-cancer agents $(1,2)$. The rationale for such development lies in the fact that the degree of acetylation/deacetylation of histone proteins is closely related to the configuration of nuclear chromatin. Low levels of acetylation are associated with a condensed conformation (heterochromatin), which is densely packed and transcriptionally inactive, whereas a high degree of acetylation is associated with a loose configuration (euchromatin), which is less compact and subject to transcriptional processes and gene expression $(2,3)$. Since cancer cell phenotype is usually characterized by poor differentiation and the inappropriate silencing of tumor suppressor genes, the reactivation of gene expression, triggered by HDAC inhibitors, might prove potentially useful in cancer treatment $(2,4)$. In this regard, it was recently reported that trichostatin enhances the expression of DLC-1 gene, which is located on chromosome 8p21-22, a region frequently deleted in prostate carcinomas (5).

Among the HDAC inhibitors, the short-chain carboxylic acid, valproic acid (VA), presents some peculiarities. The drug primarily inhibits class I HDAC and induces the proteasomal degradation of class II HDAC (6-8). Most importantly, VA was introduced as an anti-epileptic agent decades ago and its safety profile has now been well established. Therefore, it has the potential for faster clinical development as an anti-cancer drug. Indeed, VA is currently under clinical evaluation, either as a single agent or in combination therapy, for acute myeloid leukemia and myelodysplastic syndromes $(9,10)$. Despite its potential advantages, VA displays poor specificity and selectivity of action. Nevertheless, other putative mechanisms, apart from HDAC inhibition, may account for VA anti-tumor activity (11). Moreover, DNA microarray analysis has shown that a large number of different genes are modulated by VA treatment, either as re-expression or silencing, in various experimental paradigms $(12,13)$. Thus, the potential for clinical exploitation of VA for cancer treatment needs to be carefully assessed in pre-clinical testing.

Graziani et al previously showed that VA positively modulates the expression of estrogen receptor $\alpha$ and 
significantly enhances the proliferative activity exerted by $17-\beta$-estradiol in human endometrial and breast cancer cell lines (14). In addition, VA has been reported to lower the expression of the anti-apoptotic gene bcl-2 and increase Ecadherin (E-cad) in estrogen-insensitive endometrial cancer cells, while it restores and enhances the expression of RARB2, a prototypical silenced tumor suppressor gene, in estrogen-sensitive and -insensitive breast cancer cells $(15,16)$.

Certain data presented in the literature indicate that the anti-proliferative action of VA also occurs in prostate cancer cells. Thelen et al demonstrated that VA induces apoptosis in androgen-sensitive LNCaP cells, associated with a downregulation of the prostate-specific proliferation factor and prostate specific antigen (PSA) as well as with an up-regulation of anti-proliferative and pro-apoptotic factors such as insulinlike growth factor binding protein-3 and the tissue inhibitor of matrix metalloproteinase 3 (17). More recently, Angelucci et al have shown that VA, through the down-regulation of bcl-2, is a potent apoptotic inducer, mainly in less-differentiated prostate cancer cell lines (18).

Androgen activity in prostate cancer cells is mediated by the androgen receptor (AR), a ligand-modulated transcription factor belonging to the nuclear receptor superfamily $(19,20)$. Notably, most co-activators and co-repressors share the capacity to influence the transcriptional potential of the receptor by regulating the acetylation status of androgen responsive genes and/or the AR itself, through their respective histone acetyltransferase (HAT) or HDAC activity. Certain authors have shown that co-activators enhance the inherent transcriptional activity of the AR by direct receptor acetylation and up-regulate the transcriptional rate by histone acetylation of the AR target genes $(21,22)$. Conversely, AR activity has been shown to be down-regulated by HDAC1 in a deacetylasedependent manner, suggesting that a reversal of HAT activity is important in abrogating AR function (23). An increase in AR activity associated with the activation of the androgenregulated PSA gene without a modification of AR levels in LNCaP cells treated with HDAC inhibitors was observed by Korkmaz et al (24).

In our study, we report on the activity of VA on cell growth, androgen-responsiveness and AR levels not only of the above mentioned LNCaP cells, but also of the androgeninsensitive PC-3 cells, which, in our experience, possess low levels of AR (25). We provide evidence that VA, used at a concentration of clinical interest, has anti-proliferative activity in LNCaP and PC-3 cells and shows cytotoxic effect when used at high doses. In addition, we demonstrate that VA abrogates androgen mitogenic activity in LNCaP cells, while it induces a response to androgens in PC-3 cells. The involvement of AR in this event may be postulated for PC-3 cells since we have observed an early increase in AR amount, while the enhanced level of AR in LNCaP cells merits further investigation. In PC-3 cells, the increase in AR expression is coupled with an increase in the expression of E-cad involved in adhesion mechanisms and present at the level of intercellular junctions. In prostate carcinoma, aberrant expression of E-cad has often been observed and its loss of function has been associated with enhanced metastatic growth (26-28).

\section{Materials and methods}

Compounds. Valproic acid (VA) and 5 $\alpha$-dihydrotestosterone (DHT) were purchased from Sigma-Aldrich (St. Louis, MO, USA). Stock solutions were obtained by dissolving VA in the media weekly and DHT in absolute ethanol. The two were stored at $4^{\circ} \mathrm{C}$. The vehicle did not exceed the final concentration of $0.1 \%$.

Cells. The hormone-sensitive LNCaP cell line was used between passages 41 and 46 and cultured in RPMI-1640 medium (Eurobio, Les Ulis Cedex B, France), supplemented with $10 \%(\mathrm{v} / \mathrm{v})$ foetal bovine serum (FBS, ICN Biomedicals, Costa Mesa, CA, USA), 10 mM HEPES buffer (Eurobio) and antibiotics.

The hormone-insensitive PC-3 cells were used between passages 82 and 103 and routinely cultured in DMEM, supplemented with 5\% FBS, HEPES buffer and antibiotics.

The two cell lines were sub-cultured weekly. They were maintained in humidified air: $\mathrm{CO}_{2}$ atmosphere (95\%:5\%) at $37^{\circ} \mathrm{C}$.

Proliferation experiments. Subconfluent LNCaP and PC-3 cells were trypsinized and plated out at a density of 50,000 cells or 25,000 cells $/ \mathrm{ml}$ of standard culture medium, respectively, in $60-\mathrm{mm}$ plastic petri dishes. Cells were allowed to adhere and 1 (PC-3 cells) or 2 days (LNCaP cells) after plating the seeding media were changed with fresh media supplemented with $5 \%$ charcoal-treated FBS (CH-FBS) and containing VA (0.45-25 mM).

In order to assess whether VA was able to modulate the androgen sensitivity of our models, the two drugs were used in different modalities.

In a series of experiments, LNCaP cells were treated with DHT at concentrations from $10^{-11}$ to $10^{-5} \mathrm{M}$ alone or combined with $0.45 \mathrm{mM}$ VA, while PC-3 cells were exposed to DHT $\left(10^{-10}-10^{-8} \mathrm{M}\right)$ alone or in association with $0.45 \mathrm{mM}$ VA.

In other experiments, $\mathrm{LNCaP}$ and $\mathrm{PC}-3$ cells were pretreated for 2 days with $0.45 \mathrm{mM} \mathrm{VA}$ and then exposed to $10^{-9} \mathrm{M}$ DHT.

Finally, the two cell lines were pre-treated for 6 days with $0.45 \mathrm{mM}$ VA and then, after trypsinization, they were exposed to $0.45 \mathrm{mM} \mathrm{VA}$ and $10^{-9} \mathrm{M}$ DHT alone or in association.

The medium with or without VA and DHT was changed every 2 days. In each experiment, triplicate cultures were set up for each drug concentration and control dishes without drugs with the same amount of vehicle were run in parallel.

At the end of incubation, attached cells were harvested by trypsinization and, when possible, floating cells were collected. An equal volume of $0.4 \%$ trypan blue staining solution was added to the cell suspension. Stained (dead) and unstained (viable) cells were counted under a light microscope. Cell counts were performed with a hemocytometer after 2, 4 and 6 days of treatment.

Morphological observation of treated and untreated cells. LNCaP and PC-3 cells untreated or treated with VA or DHT were observed and photographed under an inverted phase contrast microscope at $\mathrm{x} 400$ magnification. 
$A R$ determination by reverse transcriptase-polymerase chain reaction $(R T-P C R)$. An analysis of the expression of the AR was performed by RT-PCR in untreated cells cultured for 2 days in media supplemented with $5 \% \mathrm{CH}-\mathrm{FBS}$. At this time, the cells were washed twice with phosphate-buffered saline (PBS), detached from the plates with a cell scraper and centrifuged. Total RNA was extracted from the pellets using tripure reagent (Roche Applied Science, Milan, Italy) according to the instructions provided by the supplier.

cDNA was synthesized by incubating $1.5 \mu \mathrm{g}$ total RNA with $0.5 \mathrm{U}$ of AMV RT and $0.2 \mu \mathrm{g}$ oligo(dt) primer at $42^{\circ} \mathrm{C}$ for $1 \mathrm{~h}$, using a cDNA cycle kit from Invitrogen (Carlsbad, CA). Aliquots $(5 \mu 1)$ of the reverse transcribed cDNA were subjected to 25 or 35 cycles of PCR in $50 \mu 1$ of $1 \mathrm{x}$ buffer (10 mM Tris- $\mathrm{HCl}$, pH 8.3, $1.5 \mathrm{mM} \mathrm{MgCl}_{2}, 50 \mathrm{mM} \mathrm{KCl}$ ) containing $1 \mathrm{mM}$ each of dATP, dCTP, dGTP and dTTP, 2.5 U of Taq DNA polymerase (Roche Applied Science) and $0.2 \mathrm{mM}$ of specific primers. Each cycle consisted of denaturation at $94^{\circ} \mathrm{C}$ for $60 \mathrm{sec}$, annealing at $55^{\circ} \mathrm{C}$ for $70 \mathrm{sec}$ and an extension at $72^{\circ} \mathrm{C}$ for $70 \mathrm{sec}$.

The primer pairs used for AR were (5'-GCATGGTGAGC AGAGTGCCCTATC-3' and 5'-TCCCAGAGTCATCCCTG CTTCAT- $3^{\prime}$ ) and amplified a $365 \mathrm{bp}$ fragment. The primers used for glyceraldehyde-3 phosphate dehydrogenase (GAPDH) amplification (5'-TGGTATCGTGGAAGGACTC ATGAC-3' and 5'-ATGCCAGTGAGCTTCCCGTTCAGC-3') amplified a $190 \mathrm{bp}$ product. PCR products $(20 \mu 1)$ were electrophoresed through a $2 \%$ agarose gel containing ethidium bromide.

$A R$ and E-cad determination by immunoblot analysis. AR expression was evaluated in cells untreated or treated with $0.45 \mathrm{mM} \mathrm{VA}$ and $10^{-9} \mathrm{M}$ DHT alone or in combination after 1, 2, 4 and 6 days of exposure. LNCaP and PC-3 cells were trypsinized and seeded at the proper density in $100-\mathrm{mm}$ plastic plates. Treatments were performed as previously described in the section 'Cell proliferation experiments'. At each treatment time, plates were placed on ice and cells removed from the plate using a scraper and then washed twice with PBS by centrifugation. The final pellets were solubilized in RIPA buffer (50 mM Tris-HCl, pH 8.0, $150 \mathrm{mM} \mathrm{NaCl,} \mathrm{0.1 \%} \mathrm{sodium}$ dodecyl sulphate, SDS, $1 \%$ Nonidet P40, $0.5 \%$ sodium deoxycholate, $100 \mu \mathrm{g} / \mathrm{ml}$ phenylmethylsulfonylfluoride, $1 \mathrm{mM}$ $\mathrm{Na}_{3} \mathrm{VO}_{4}, 30 \mu \mathrm{g} / \mathrm{ml}$ aprotinin) to give whole cell lysates. Protein concentration was established using the Lowry method (29), and equal amounts of total proteins $(50 \mu \mathrm{g}$ of $\mathrm{LNCaP}$ or $100 \mu \mathrm{g}$ of PC-3) were mixed with a loading buffer $(62.5 \mathrm{mM}$ Tris-HCl, pH 6.8, 2\% SDS, 10\% glycerol, 1\% 2-mercaptoethanol, $0.005 \%$ bromophenol blue), boiled, fractionated in a $8 \%$ SDS-PAGE and transferred into polyvinylidene difluoride membrane (Immobilon P, Millipore, Bedford, MA, USA). Membranes were then probed with a monoclonal antibody anti-AR (AR441, Biomeda, Foster City, CA) at 1:1,000 or with a monoclonal antibody anti-E-cad (clone 4A2CI, Zymed Laboratories Inc., St. Francisco, CA, USA) at 1:2,000 in

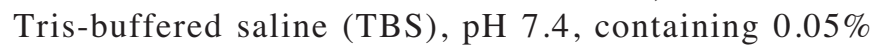
Tween-20 (TBST) and 5\% fat-free milk. The membranes were then washed four times in TBST and incubated with horseradish peroxidase-conjugated secondary antibody diluted at 1:2,000-1:3,000 in TBST containing 5\% fat-free

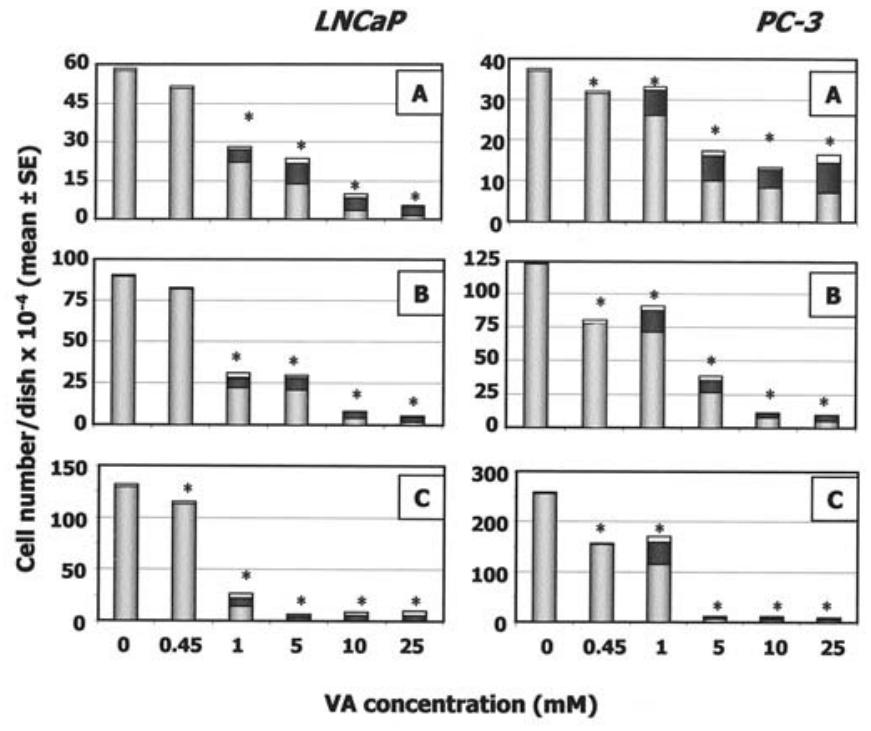

Figure 1. Effect of increasing concentrations of VA (from 0.45 to $25 \mathrm{mM}$ ) on cell growth of $\mathrm{LNCaP}$ and PC-3 cells after 2 (A), 4 (B) and 6 (C) days of treatment. Cells were cultured in media containing 5\% CH-FBS. Each column represents the mean $\pm S E$ (white portion) $(n=6)$ of the data obtained from two independent experiments run in triplicate. The dark portion of each column represents the percentage of dead cells. ${ }^{*} \mathrm{P}<0.001$, Student's t-test versus untreated cells.

milk. After washing four times in TBST, the membranes were visualized using an enhanced chemiluminescence system (ECL, Amersham, Buckinghamshire, UK) and visualized on Hyperfilm ECL (Amersham).

The membranes were hybridised with an anti- $\beta$-actin monoclonal antibody at 1:15,000, which was used as an internal control for protein loading.

The signals were quantified by densitometric scanning (ChemiDoc documentation system/Quantity one quantification software, Bio-Rad Laboratories, Hercules CA, USA). The densitometric units of the AR or E-cad were corrected for the densitometric units of $\beta$-actin. The specific $A R / \beta$-actin or E-cad $/ \beta$-actin ratio from each treated sample was then divided by the value under the control conditions in order to obtain the fold variation of each specific protein expression.

Statistical analysis. Data are expressed as mean \pm SE. A comparison between means was performed by a two-tailed Student's t-test. A p-value $<0.05$ was considered statistically significant.

\section{Results}

$V A$ inhibits cell growth of prostate cancer cells at a low concentration and has a cytotoxic effect at high doses. VA caused a dose-dependent inhibition of cell proliferation in androgen-sensitive LNCaP cells at each of the times tested (Fig. 1).

The lowest dose $(0.45 \mathrm{mM})$ determined a slight reduction in cell numbers with respect to controls only after 6 days of exposure $(\sim 14 \%, \mathrm{p}<0.001)$ and no dead cells were found as assessed by the trypan blue dye exclusion test (Fig. 1C).

By increasing the concentration of the drug (from 1 to $25 \mathrm{mM}$ ), a higher inhibition of cell growth was observed 


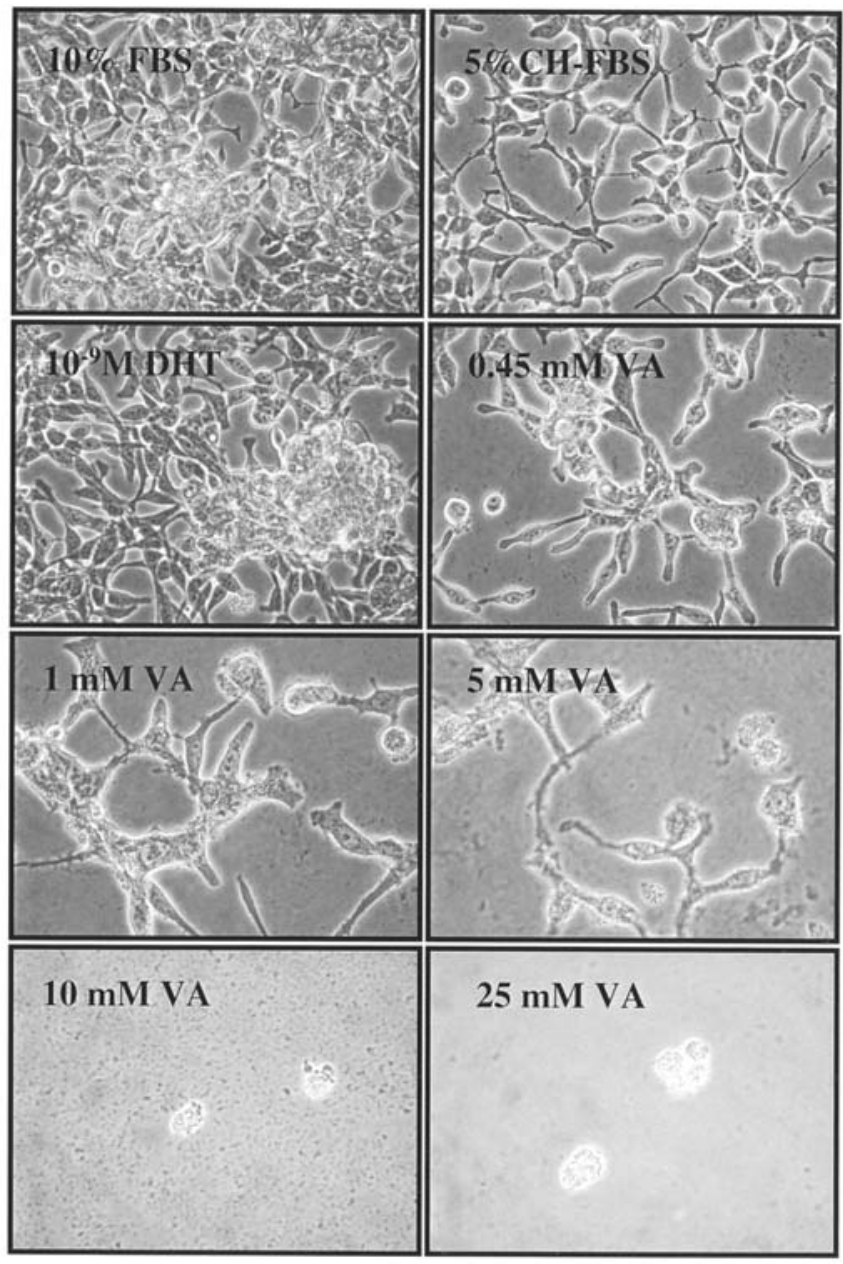

Figure 2. LNCaP cells were plated on tissue culture plates and cultured for 4 days either in the presence or absence of VA and DHT and examined live, using phase-contrast microscopy at $\mathrm{x} 400$ magnification. Cells grown in a medium containing normal serum (10\% FBS) are also shown.

after 2-6 days accompanied by a very strong reduction in cell viability. In particular, after 6 days of treatment, LNCaP cell growth was almost completely suppressed (by 89\%, p<0.001) at the highest doses and cell viability was $35 \%$ (Fig. 1).

After 2 days, the growth of androgen-insensitive PC-3 cells was reduced by $\sim 15 \%$ with respect to control, when cells were treated with $0.45 \mathrm{mM} \mathrm{VA}(\mathrm{p}<0.001)$, while after 4 and 6 days it was inhibited by $40 \%(\mathrm{p}<0.001)$. Cell viability was $>90 \%$ (Fig. 1).

A similar inhibition of cell growth was seen with $1 \mathrm{mM}$ VA, although, in this case, cell viability was strongly reduced (by 23-30\%). Increasing the concentrations of the drug from 5 to $25 \mathrm{mM}$, cell numbers sharply decreased and after 6 days of treatment the inhibition reached $90 \%$, while cell viability was reduced to $45 \%$.

At the highest doses of VA, in the two cell lines, many dead cells detached and debris were observed floating in the media. It is worth mentioning that cell numbers of the LNCaP and PC-3 cells treated with $25 \mathrm{mM} \mathrm{VA}$ were below the number of cells seeded.

VA induces morphological changes in prostate cancer cells. The effect of different culture conditions on the morphology of
LNCaP and PC-3 cells was explored after 2, 4 and 6 days of treatment. Figs. 2 and 3 refer to the variations observed after 4 days. This time frame was chosen because it was representative of the observations made with an adequate cell density and in the presence of less pronounced cytotoxic damages induced by the high VA concentrations.

Untreated LNCaP cells growing in their standard medium (10\% FBS) had a flattened and elongated morphology. They tended to grow mostly by aggregates with a somewhat acinar appearance (Fig. 2).

LNCaP cells cultured in a medium containing 5\% CH-FBS without androgens grew slowly and unclumped. In addition, they acquired a distinct neuronal-like appearance with smaller cell bodies and multiple long, thin processes (Fig. 2). The addition of $0.45 \mathrm{mM}$ VA to LNCaP cells grown in a medium supplemented with CH-FBS caused a loss in the dendritic processes, with a more rounded cell shape. Using increasing concentrations of the drug, cell morphology changed again with the re-appearance of certain cytoplasmic extensions, though cell numbers dropped dramatically and cells became vacuolated and fragmented (Fig. 2).

When DHT was combined with VA, it did not produce any further variation in cell morphology (not shown).

In the presence of the androgen alone, $\mathrm{LNCaP}$ cells grew and took the appearance of those cultured in their standard medium (Fig. 2).

Control PC-3 cells showed an epithelial-like cell morphology with spherical grapelike aggregates, consistent with the PC-3 cell line as originally described (Fig. 3). The three representative morphological cell types observed were: a) monolayers attached to the plastic surface, b) monolayers with certain cells piling up in the centre as focal points and c) densely packed multi-layered cell patches with limited cell spreading.

No changes in these aspects were observed when the cells were cultured in a medium supplemented with 5\% CH-FBS. The addition of $0.45 \mathrm{mM}$ VA resulted in a relative enlargement of cells adherent to the culture plates and a diminution in cell clusters. With increasing concentrations of the drug, cell membranes gradually became irregular, vacuolization occurred and, finally, cells appeared shrunken and detached (Fig. 3).

The addition of DHT to the culture medium did not induce any variation in cell morphology, when compared with cells grown in their standard medium or in a medium containing 5\% CH-FBS (Fig. 3).

VA modulates androgen sensitivity of prostate cancer cells. The concentration of $0.45 \mathrm{mM} \mathrm{VA}$, which did not affect cell viability, was chosen to test whether the drug might influence the response to the androgen in the $\mathrm{LNCaP}$ and $\mathrm{PC}-3$ cells. Three different modalities of cell treatment were used: i) VA was added to the culture medium at the same time as DHT; ii) cells were pre-treated for 2 days with VA and then exposed to DHT and iii) cells were pre-treated with VA for 6 days and then detached, seeded at their initial culture density, and treated with VA, DHT or an association of VA/DHT.

LNCaP cell line. In agreement with our previous results (30), DHT determined a growth response with a biphasic curve in $\mathrm{LNCaP}$ cells. At low DHT concentrations (from $10^{-10}$ to 


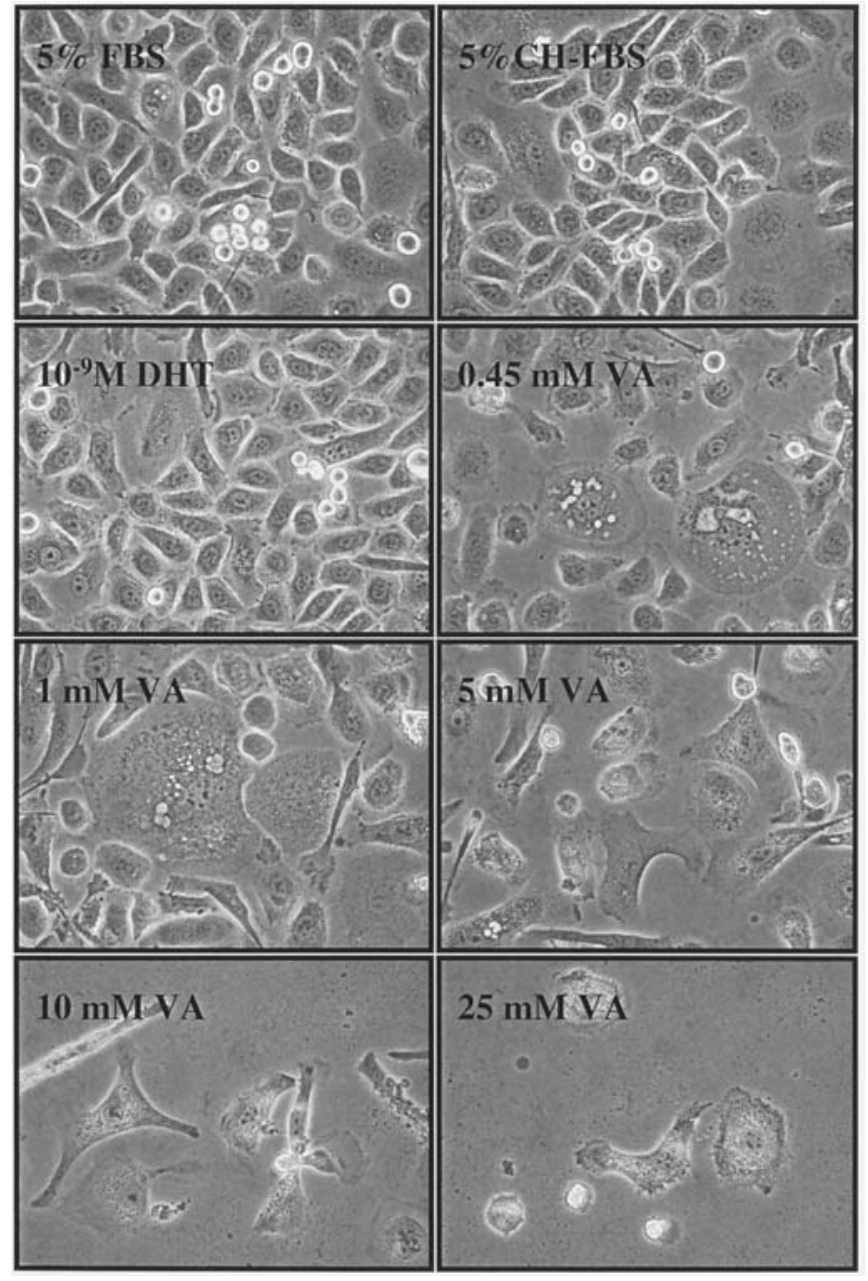

Figure 3. PC-3 cells were plated on tissue culture plates and cultured for 4 days either in the presence or absence of VA and DHT and examined live, using phase-contrast microscopy at $\mathrm{x} 400$ magnification. Cells grown in a medium containing normal serum (5\% FBS) are also shown.

$\left.10^{-8} \mathrm{M}\right)$, there was an increase in cell numbers at each of the times examined. The dose of $10^{-7} \mathrm{M}$ DHT had a mitogenic activity only after 4 and 6 days of treatment. The highest stimulation $(\sim 80 \%$ with respect to control, $\mathrm{p}<0.001)$ was obtained with $10^{-9}$ and $10^{-8} \mathrm{M}$ DHT after 4-6 days of exposure. Higher DHT concentrations $\left(10^{-6}\right.$ and $\left.10^{-5} \mathrm{M}\right)$ reduced cell proliferation. The maximal inhibition was obtained with $10^{-5} \mathrm{M}$ DHT (25\% after 6 days of treatment, $\mathrm{p}<0.001$ ) (Fig. 4).

The addition of $0.45 \mathrm{mM}$ VA to DHT not only completely suppressed androgen-stimulated cell proliferation, but it also significantly reduced cell numbers below the controls (untreated cells). When VA was associated with $10^{-9}-10^{-7} \mathrm{M}$ DHT, the inhibition reached $\sim 25 \%$ ( $<<0.001$ ) after 4-6 days of treatment (Fig. 4). The combination of VA with the highest concentrations of DHT tested $\left(10^{-6}\right.$ and $\left.10^{-5} \mathrm{M}\right)$, which per se showed inhibitory activity, led to a more pronounced reduction in cell proliferation after 4 and 6 days of treatment when the inhibition reached $35 \%$ with the association $\mathrm{VA} / 10^{-5} \mathrm{M}$ DHT $(\mathrm{p}<0.001)$.

In addition, the combination $\mathrm{VA} /\left(10^{-10}-10^{-7} \mathrm{M}\right) \mathrm{DHT}$ inhibited cell growth more than VA on its own $(\mathrm{p}<0.001)$ after a 6-day treatment (Fig. 4).

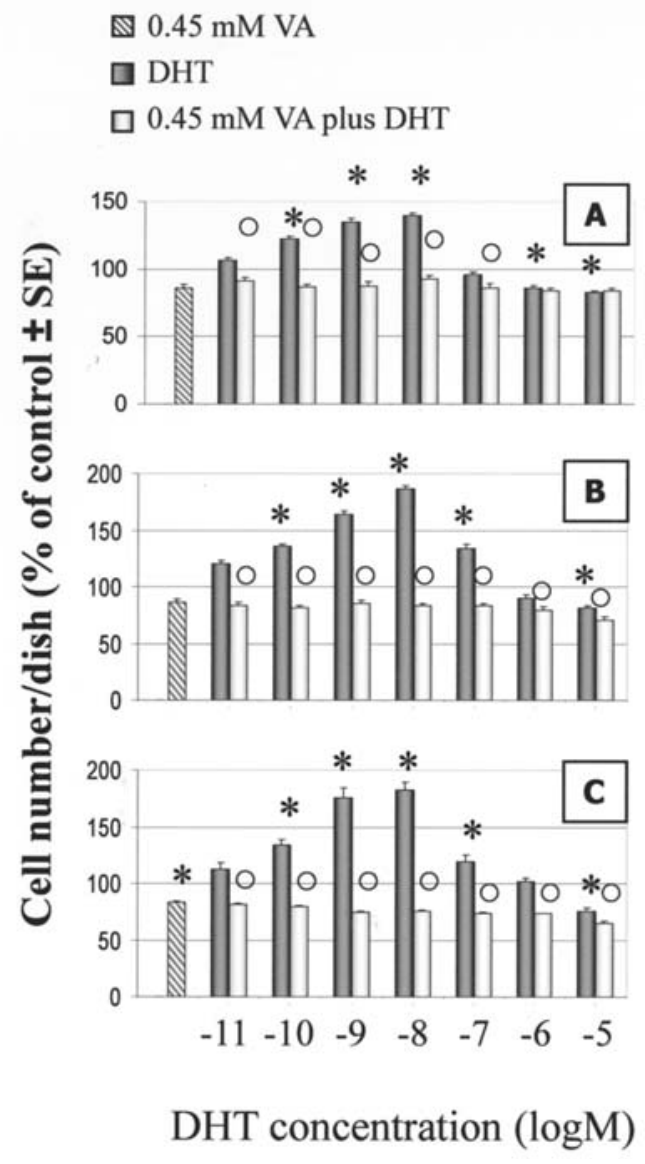

Figure 4. Effect of increasing concentrations of DHT (from $10^{-11}$ to $10^{-5} \mathrm{M}$ ) alone or associated with $0.45 \mathrm{mM} \mathrm{VA}$ on the growth of LNCaP cells after 2 (A), 4 (B) and 6 (C) days of treatment. The effect of $0.45 \mathrm{mM}$ VA used alone is also reported. Cells were cultured in media containing $5 \% \mathrm{CH}-\mathrm{FBS}$. Each column represents the mean $\pm \mathrm{SE}(n=6)$ of the data obtained from two independent experiments run in triplicate. ${ }^{*} \mathrm{P}<0.001$, Student's $\mathrm{t}$-test versus untreated cells. ${ }^{\circ} \mathrm{P}<0.001$, Student's t-test versus DHT-treated cells.

The concentration of $10^{-9} \mathrm{M}$ DHT, which is close to the dissociation constant ( $\mathrm{kDa}$ ) value of the AR and highly stimulates cell growth, was chosen in the experiments aimed at evaluating whether VA pre-treatment could affect the androgen-induced cell proliferation.

When LNCaP cells were pre-treated for 2 days with $0.45 \mathrm{mM}$ VA and then exposed to DHT, they behaved differently in respect to the time of androgen treatment. After 2 days, they still responded to DHT showing a significant increase $(38 \%, \mathrm{p}<0.001)$ in cell growth, while after 4 and 6 days they did not show any significant variation in cell proliferation with respect to control. Growth inhibition was observed in cells exposed to VA for 4 days $(28 \%, \mathrm{p}<0.001)$, while at the other times cell numbers matched the controls. The combination of VA/DHT after VA pre-treatment left unmodified cell numbers with respect to VA treated cells (Fig. 5A). When VA pre-treatment was prolonged to 6 days, a further exposure to the HDAC inhibitor caused a greater reduction in cell numbers than that observed in LNCaP cells without pre-treatment or pre-treated for 2 days. The cell growth inhibition reached $40 \%$ with respect to control after 6 days $(\mathrm{p}<0.001)$. When VA pre-treatment was followed by DHT exposure, the response of LNCaP cells to the androgen lacked after 2 days and was lowered after 4 and 6 days with 


\section{LNCaP}

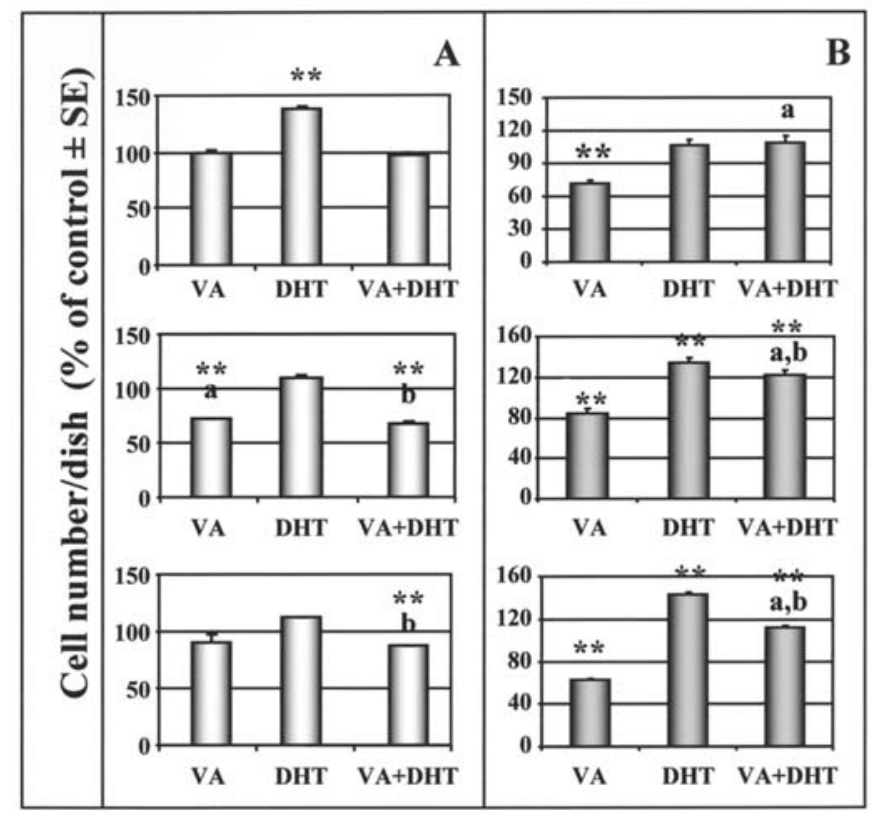

Figure 5. Effect of $10^{-9} \mathrm{M}$ DHT and $0.45 \mathrm{mM} \mathrm{VA}$, alone or in association, on the growth of LNCaP cells pre-treated for 2 (A) or 6 days (B) with $0.45 \mathrm{mM}$ VA (see Materials and methods). Cell counts were performed after 2 (top), 4 (middle) and 6 (below) days of treatment. Cells were cultured in media containing $5 \% \mathrm{CH}-\mathrm{FBS}$. Each column represents the mean $\pm \mathrm{SE}(\mathrm{n}=6)$ of the data obtained from two independent experiments run in triplicate. ${ }^{* *} \mathrm{P}<0.001$, Student's t-test versus untreated cells. ${ }^{\mathrm{a}} \mathrm{P}<0.01$, Student's $\mathrm{t}$-test versus VA-treated cells. ${ }^{b} \mathrm{P}<0.01$, Student's t-test versus DHT-treated cells.

respect to that of the $\mathrm{LNCaP}$ cells, which were not pre-treated (Fig. 4).

After 2 days, if the cells were treated with the combination of VA/DHT, cell numbers were higher than those of VAtreated cells, though did not differ from those of DHT-treated cells. After 4 and 6 days, the combination determined a similar trend, but cell numbers were lower with respect to DHT-treated cells (Fig. 5B).

$P C-3$ cell line. As expected, in the PC-3 cells, $10^{-10}-10^{-8} \mathrm{M}$ DHT did not affect cell proliferation. Nevertheless, the addition of DHT to $0.45 \mathrm{mM}$ VA influenced its inhibitory action. DHT at $10^{-9}$ and $10^{-8} \mathrm{M}$ suppressed VA induced growth reduction after 2 and 4 days, while $10^{-10} \mathrm{M}$ DHT produced the same effect after 4 and 6 days of treatment. Moreover, after 6 days of exposure, $10^{-9}$ and $10^{-8} \mathrm{M}$ DHT were not only able to counteract the inhibitory action of VA, but to induce a weak increase in cell numbers with respect to control (Fig. 6).

When PC-3 cells were exposed to $0.45 \mathrm{mM}$ VA for 2 days and then treated with the same concentration of the drug, a cell growth reduction that reached $50 \%$ with respect to control was observed after 6 days. When PC-3 cells, pre-treated with VA for 2 days, were subsequently exposed to DHT, there was no response after 2 or 4 days of androgen treatment. However, a reduction in cell growth was seen $(21 \%$ with respect to control, $\mathrm{p}<0.001)$ after 6 days. When VA and DHT were associated, cell numbers were higher after 2 and 4 days, though were similar to those of VA-treated cells after 6 days, suggesting once again that a certain interference occurred between the androgen and the HDAC inhibitor. The association of the
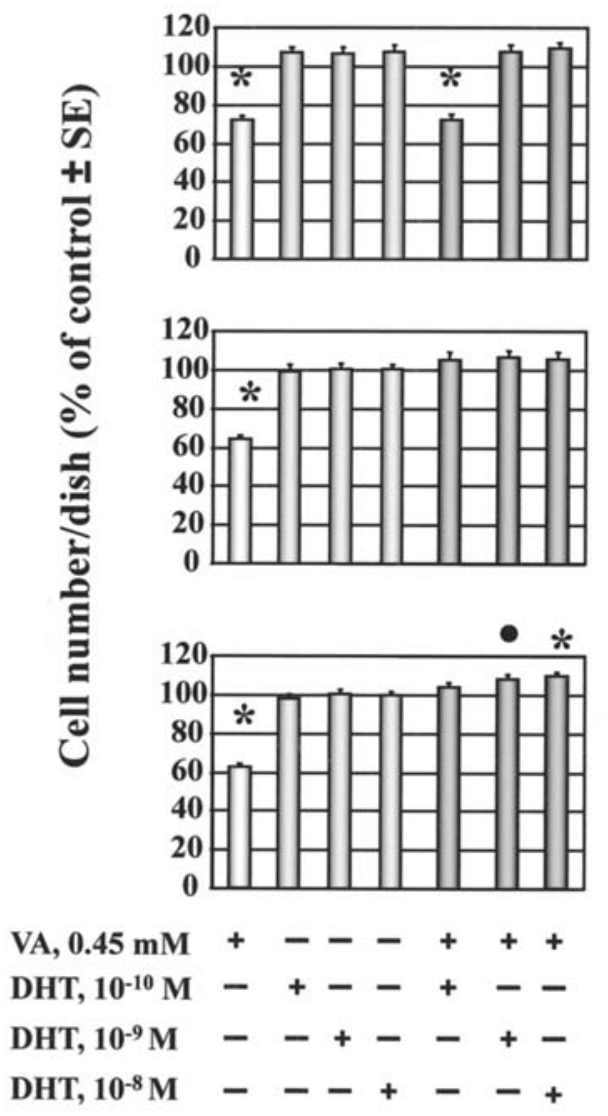

Figure 6. Effect of DHT (from $10^{-10}$ to $10^{-8} \mathrm{M}$ ) alone or associated with $0.45 \mathrm{mM}$ VA on the growth of PC-3 cells after 2 (top), 4 (middle) and 6 (below) days of treatment. The effect of $0.45 \mathrm{mM} \mathrm{VA}$ alone is also reported. Cells were cultured in media containing 5\% CH-FBS. Each column represents the mean $\pm S E(n=6)$ of the data obtained from two independent experiments run in triplicate. ${ }^{\circ} \mathrm{P}<0.05$ and ${ }^{*} \mathrm{P}<0.01$, Student's t-test versus untreated cells.

two compounds did not promote any additional inhibitory action (Fig. 7A).

After a 6-day pre-treatment with VA, PC-3 cell proliferation was greatly reduced by further VA exposure. The inhibition reached $60 \%$ with respect to control $(\mathrm{p}<0.001)$, after 6 days. Under these conditions, $10^{-9} \mathrm{M}$ DHT induced a remarkable stimulation in cell growth (maximum $40 \%$ after 4 days). The combination of VA/DHT reduced the effect shown by VA and DHT when used alone (Fig. 7B).

$V A$ affects $A R$ expression in prostate cancer cells. At a different level, LNCaP and PC-3 cells express AR. The expression was assessed by RT-PCR and Western blotting and the data concerning PC-3 cells are in agreement with our previous results obtained with biochemical and immunocytochemical assays (24). As shown in Fig. 8, using a pair of primers specific to the AR CDNA, we were able to detect the expression of AR mRNA in the LNCaP cell line after 25 cycles of PCR. Additional PCR cycles allowed us to detect the expression of AR mRNA in the PC-3 cells, indicating that the steady-state AR mRNA levels in the PC-3 cells are relatively much lower than in the LNCaP cells (Fig. 8).

Western blot analysis showed that AR protein is expressed in $\mathrm{LNCaP}$ and PC-3 cells at the right molecular weight, confirming the results obtained by RT-PCR (Fig. 8). 


\section{$P C-3$}

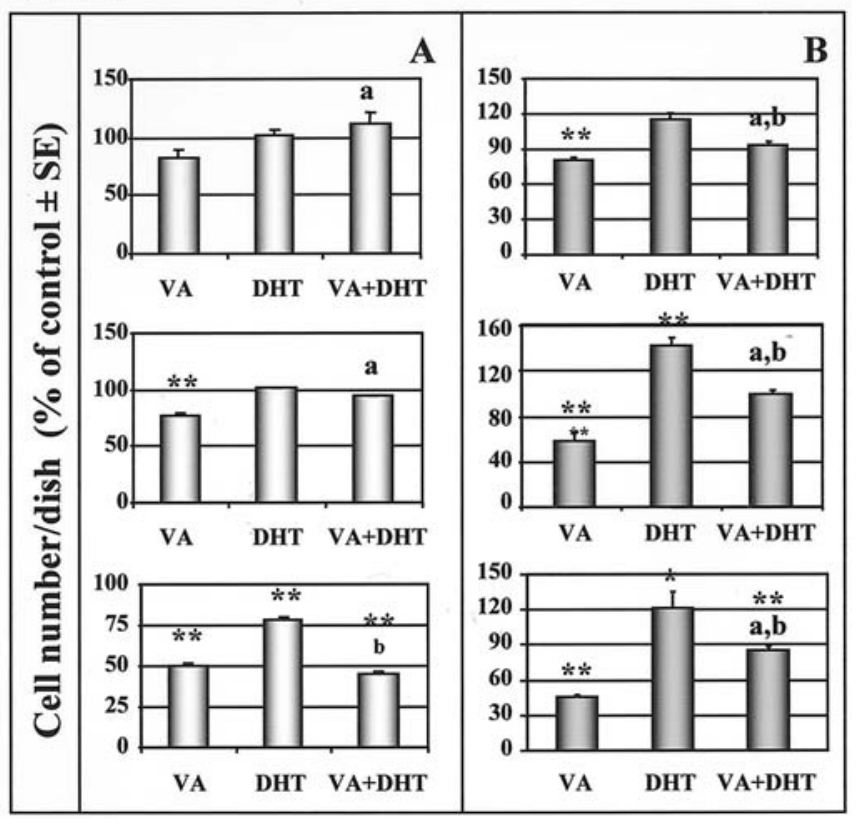

Figure 7. Effect of $10^{-9} \mathrm{M}$ DHT and $0.45 \mathrm{mM} \mathrm{VA}$, alone or in association, on the growth of PC-3 cells pre-treated for 2 (A) or 6 days (B) with $0.45 \mathrm{mM}$ VA (see Materials and methods). Cell counts were performed after 2 (top), 4 (middle) and 6 (below) days of treatment. Cells were cultured in media containing $5 \% \mathrm{CH}-\mathrm{FBS}$. Each column represents the mean $\pm \mathrm{SE}(\mathrm{n}=6)$ of the data obtained from two independent experiments run in triplicate. ${ }^{*} \mathrm{P}<0.01$ and ${ }^{* *} \mathrm{P}<0.001$, Student's t-test versus untreated cells. ${ }^{\mathrm{a}} \mathrm{P}<0.01$, Student's t-test versus VA-treated cells. ${ }^{\mathrm{b}} \mathrm{P}<0.01$, Student's t-test versus DHT-treated cells.

Immunoblotting also highlighted a higher expression level of AR in LNCaP with respect to PC-3 cells.

In the LNCaP cells, a 1-day treatment with $10^{-9} \mathrm{M}$ DHT induced an increase in AR expression (24\% with respect to control, $\mathrm{p}<0.05)$, that gradually diminished reaching the control values after 4 days (Fig. 9).

A 1, 2 or 6-day treatment with $0.45 \mathrm{mM}$ VA did not change the AR expression (data not shown), while an increase in AR levels with respect to control $(42 \%, \mathrm{p}<0.05)$ was observed after a 4-day exposure. The addition of VA to DHT did not induce any variation in the AR levels expressed in the presence of the androgen alone after 1,2 and 6 days (data not shown). However, after 4 days, the increase observed with VA was abolished by DHT confirming a possible interference of the two drugs also at the level of the receptor machinery (Fig. 10).

In the PC-3 cells, VA treatment resulted in a marked increase in AR expression (126\% with respect to control, $\mathrm{p}<0.01)$ only after 1 day. DHT, although ineffective in regulating cell proliferation, induced an augmentation in AR levels ( $42 \%$ with respect to control, $\mathrm{p}<0.01$ ). The association of VA/DHT still caused an increase in AR expression, although, to a lesser extent $(99 \%$ with respect to control, $\mathrm{p}<0.01$ ) (Fig. 10).

$V A$ enhances E-cad expression in PC-3 cells. No statistically significant change in the E-cad expression was observed when LNCaP cells were exposed to VA, DHT or their combination

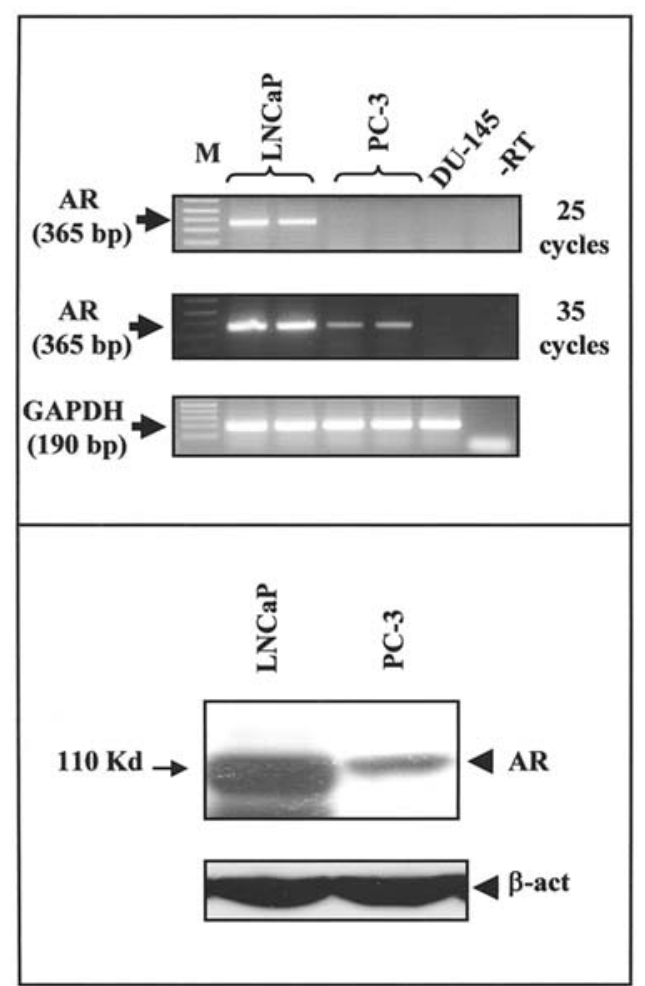

Figure 8. Top panel: RT-PCR of basal expression of AR in LNCaP and PC-3 cells. DU-145 cells were used as a negative control. M, $1 \mathrm{~Kb}$ plus DNA ladder (Invitrogen). -RT, RNA sample from LNCaP cells incubated in the absence of RT and then subjected to PCR amplification. Bottom panel represents Western blot analysis of the basal expression of $\mathrm{AR}$ in $\mathrm{LNCaP}$ and PC-3 cells (see Materials and methods).

(data not shown). On the contrary, in the PC-3 cells an increase in E-cad levels was observed after a 1-day treatment with VA (21\% with respect to control, $\mathrm{p}<0.05)$, DHT $(40 \%$ with respect to control, $\mathrm{p}<0.05$ ) or $\mathrm{VA} / \mathrm{DHT}$ (55\% with respect to control, $\mathrm{p}<0.01$ ) (Fig. 11).

\section{Discussion}

Our findings show that a low VA concentration has an antiproliferative effect on prostate cancer cells which is related to the differentiation status. VA $(0.45 \mathrm{mM})$ slightly inhibited cell growth $(14 \%)$ in more differentiated LNCaP cells compared with the remarkable diminution $(40 \%)$ in cell proliferation observed in PC-3 cells, which are less differentiated and more aggressive (31). In the two models, increasing doses of the HDAC inhibitor produce a stronger inhibitory effect associated with cell death; however, it was more marked in the LNCaP cells. It is difficult to compare our results on prostate cancer cells, showing different characteristics in terms of androgen-sensitivity, with those present in the literature since different culture conditions, VA concentrations and times of treatment were used. In particular, Angelucci et al observed that $\mathrm{IC}_{50}$ is 1.3 and $1.1 \mathrm{mM} \mathrm{VA}$ for LNCaP and PC-3 cells, respectively. On the contrary, Annicotte et al reported that VA treatment results in decreased proliferation, evaluated by BrdU assay, in LNCaP and PC-3 cell lines, the effect being more pronounced in androgensensitive cells $(18,32)$. Abdul and Hoosein have shown that 


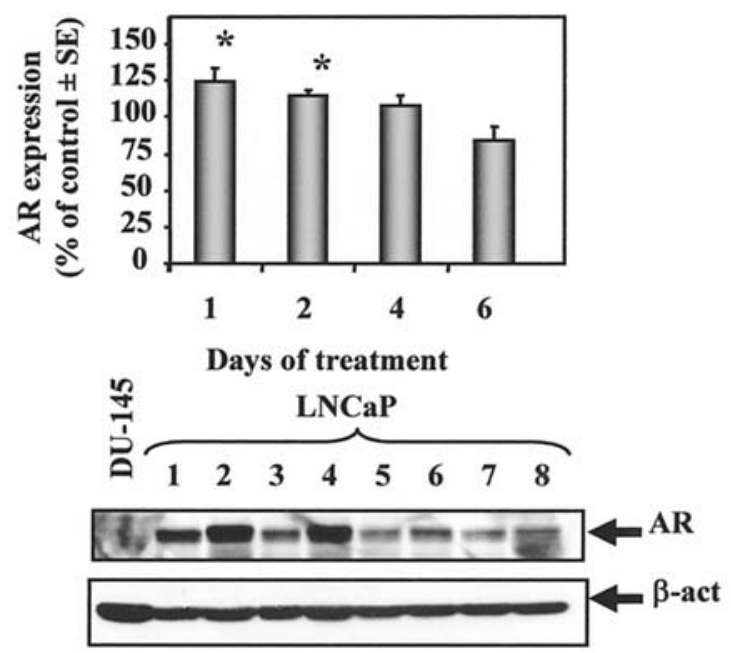

Figure 9. Time course (from 1 to 6 days) of AR expression in LNCaP cells treated with $10^{-9} \mathrm{M}$ DHT. AR levels were analyzed by immunoblot assay, quantified by densitometry and standardized against the level of $\beta$-actin per sample. The resulting values were normalized against the values from untreated cells set as 100 . Values are the mean \pm SE of two individual experiments with repeated determinations. Immunoblot from a representative experiment is shown below. DU-145 (negative control). Untreated cells (lanes 1, 3, 5, 7). DHT-treated cells (lanes 2, 4, 6, 8). ${ }^{*} \mathrm{P}<0.05$, Student's t-test versus untreated cells.

VA has the same inhibitory activity on the growth of androgen-sensitive and -insensitive cell lines, when they are cultured on Matrigel (33).

In this context, Maier et al found that other types of HDAC inhibitors are more potent on PC-3 than on LNCaP cells (34).

Our data on the cytotoxic activity of VA, at concentrations from 1 to $25 \mathrm{mM}$, are in agreement with findings by other authors $(17,35,36)$. The extent of death varies with the different HDAC inhibitors and cell lines used and cell death is referred to as an apoptotic pathway. Fronsdal and Saatcioglu showed that HDAC inhibitor treatment induces cell shrinkage and nuclear condensation as well as caspase activation (35). This last result has been confirmed by Thelen et al (17). In addition, Angelucci et al have revealed that bcl-2 downregulation has a central role in the induction of apoptosis (18).

For the first time, our study highlights that the treatment with therapeutic doses of VA is able to counteract or suppress the effect of cell growth stimulation produced by androgens in LNCaP cells. On the contrary, in PC-3 cells, VA treatment in association or in sequential modality with androgen induces a response to DHT which was not present before. In particular, after a 6-day pre-treatment with VA, a remarkable cell growth stimulation was observed. Notably, the VA concentration that produces these effects is the same as that reported to regulate histone deacetylation (14).

We were able to detect AR in LNCaP and PC-3 cells at RNA and protein levels, although to a lesser extent in androgen-unresponsive cells. This is in agreement with recent data in the literature $(37,38)$ that confirm the presence of AR in PC-3 cells. For many years this was contradicted and only our group has been able to show the presence of AR in this cell line at the protein level, in biochemical and immunocytochemical assays (25). Moreover, it is worth mentioning that

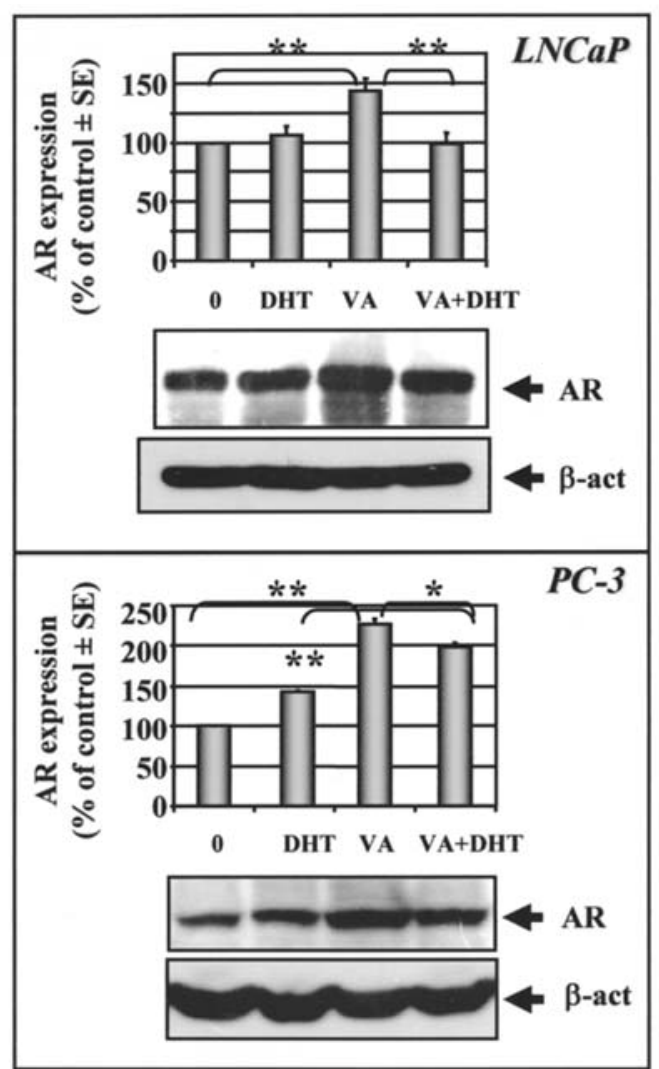

Figure 10. Top panel: Western blot analysis of AR expression in LNCaP cells exposed to $10^{-9} \mathrm{M}$ DHT and $0.45 \mathrm{mM}$ VA alone or in association for 4 days. Bottom panel: Western blot analysis of AR expression in PC-3 cells exposed to $10^{-9} \mathrm{M}$ DHT and $0.45 \mathrm{mM}$ VA alone or in association for 1 day. AR levels were analyzed by immunoblot assay, quantified by densitometry and standardized against the level of $\beta$-actin per sample. The resulting values were normalized against the values from untreated cells set as 100 . Values are the mean \pm SE of two individual experiments with repeated determinations. Immunoblot from a representative experiment is shown below each panel. Untreated cells (0). ${ }^{*} \mathrm{P}<0.05$ and ${ }^{* *} \mathrm{P}<0.01$, Student's t-test.
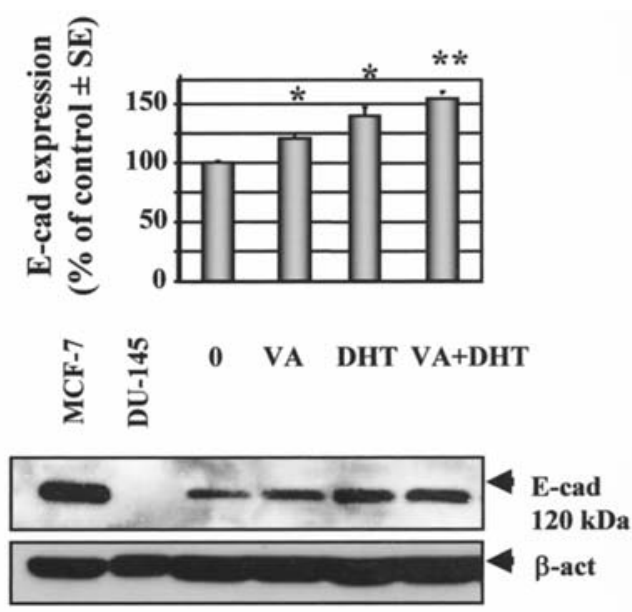

Figure 11. Western blot analysis of E-cad expression in PC-3 cells exposed to $10^{-9} \mathrm{M}$ DHT and $0.45 \mathrm{mM}$ VA alone or in association for 1 day. E-cad levels were analyzed by immunoblot assay, quantified by densitometry and standardized against the level of $\beta$-actin per sample. The resulting values were normalized against the values of untreated cells set as 100. Values are the mean $\pm \mathrm{SE}$ of two individual experiments with repeated determinations. Immunoblot from a representative experiment is shown. Untreated cells (0). MCF-7 cells (positive control). DU-145 cells (negative control). ${ }^{*} \mathrm{P}<0.05$ and ${ }^{* *} \mathrm{P}<0.01$, Student's t-test versus untreated cells. 
PC-3 cells express normal AR when compared to LNCaP cells, which contain a mutated AR (39). As expected, in LNCaP cells AR is regulated by DHT treatment, which is in agreement with the literature $(38,40)$. Notably, a similar increase of AR is observed under DHT treatment in PC-3 cells, which raises some questions on the efficiency of the AR machinery in these cells. This is in accordance with the few data in the literature $(37,38)$.

In the LNCaP and PC-3 cell lines, an enhancement in AR was found due to treatment with a low concentration of VA, even if after different times of exposure. The increase was higher in PC-3 cells, which might be related to the restoration of hormone sensitivity in this model.

Another mechanism involved in restoring androgensensitivity in the PC-3 cells might be represented by a potentiation of AR transcriptional activity by the inhibition of histone deacetylation (24). The HAT acetylation of AR is induced by ligand DHT, which promotes cell survival and increases the transcription of a subset of growth control target gene promoters. The HDAC1 (class I) binding to the AR is dissociated by the ligand DHT or by treatment with HDAC inhibitors (21).

The reason why the VA-induced increase in AR expression in the LNCaP cells is accompanied by diminution in DHTstimulated cell growth may be explained by the presence of a mutated receptor in these cells with an altered function. LNCaP cells respond with a decrease in cell numbers when they are treated with high concentrations of DHT and with an increase in cell proliferation when exposed to the antiandrogen hydroxyflutamide $(39,41)$.

Halkidou et al demonstrated that AR activation by the synthetic androgen R1881 in LNCaP cells determines the nuclear translocation of HDAC4 (class II) promoting cell growth (42). The loss of androgen-sensitivity in LNCaP cells by VA may be due to the fact that it inhibits class II enzymes, although, to a lesser extent than class I. The evidence that anti-convulsant treatment, including VA, is associated with a high prevalence of reproductive dysfunctions (i.e. androgen deficiency symptoms in men) due to anti-androgenic activity might support this hypothesis (43).

A slight increase in AR expression by VA in the LNCaP cell line has also been reported by Xia et al (36) although they used higher concentrations (1.2 and $5 \mathrm{mM})$ than ours. Moreover, these authors found that VA as well as androgen withdrawal decreased cell proliferation in an androgenindependent, though androgen-responsive cell line (C4-2) (36).

Our result related to AR enhancement induced by a low concentration of VA in LNCaP is not in agreement with data from Valentini et al who showed that 1-5 mM VA decreased AR protein and down-regulated the AR co-regulator ARA24 and PSA (44). It can be hypothesized that the different observed effects on AR expression may be strictly linked to the dose used in the experiments.

Our data regarding androgen-insensitive prostate cancer cells are similar to those obtained in endometrial and mammary cancer cell lines, where VA has been reported to increase the proliferative response to $\beta$-estradiol via the induction of estrogen receptor $\alpha$ (14).

These findings may be ascribed to the differentive activity of VA and in this context can be included the observations referring to E-cad. It is well known that E-cad expression is one of the major factors that inhibits metastasis and invasion of prostate cancer cells. The down-regulation of this expression contributes to certain aspects of oncogenesis and has been associated with the progression of prostate cancers into androgen independency (25-27). We consistently found an increased expression of E-cad in PC-3 cells treated with VA, which coincides with the AR increase, while no variation in the expression of the adhesion molecule has been found in LNCaP cells. Our results are in agreement with data from Annicotte et al, who, in addition, found that VA has no effect on the low metastatic potential of LNCaP cells, while it decreases the invasion of highly metastatic PC-3 cells (32). It is worth mentioning that HDAC inhibitors, including VA, up-regulate the expression of tight junction proteins in cell lines of different histogenesis (45), maintaining the normal tissue architecture.

We also observed that VA regulates cell shape, inducing a low concentration of the drug the disappearance of the dendritic-like processes present in androgen-starved LNCaP cells. VA attributable changes are similar to those induced by DHT, which is known to repress the neuroendocrine phenotype via AR $(46,47)$. High doses of VA (1-5 mM) determined in the few cells adherent to the culture plate the re-expression of cytoplasmic extensions, which seems in agreement with findings by Valentini et al (44). These authors, apart from the effects on cell morphology attributable to neuroendocrine-like differentiation, found an increase in the expression of neuron-specific enolase and a decrease in PSA. For these reasons, they affirm that the action of VA must be further investigated before considering it for therapeutic protocols in prostate cancer.

In PC-3 cells, the cell enlargement and diminution in cell clusters produced by VA are similar to the effects induced by tributyrin, another HDAC inhibitor $(34,48)$. In addition, such morphology has been described by Litvinov et al in a nonimmortalized in vitro human prostate cell line, which seems to refer to an intermediate cell profile deriving from transit-amplifying precursors maturing into luminal-secretory cells (49). The morphological changes associated with an increase in AR and E-cad in PC-3 cells are again conceivable with VA as a differentiation-inducing agent, that is consistent with data in the literature related to the activity of HDAC inhibitors (50).

In our experience, the VA effect may be compared to that of other differentiating agents such as interferons, which determine the reduction in cell proliferation, an increase in AR levels, the restoration of androgen-sensitivity (25) and an increase in E-cad expression (51) in PC-3 cells.

Our data clearly indicate that the global effects produced by VA may support its possible role in prostate cancer therapy, even if we think that other studies are required to clarify the different aspects of VA activity in prostate cancer cells.

On the basis of our findings and reports from the literature, its use may be suitable in androgen-sensitive and insensitive tumors.

The use of high doses of VA, even if it is much more effective on cell proliferation, seems to raise concern in view of the observed neuroendocrine-like differentiation, which is involved in prostate cancer progression $(44,52)$. On the 
contrary, low doses of VA seem to be adequate. They not only counteract the growth subordinated to the presence of DHT, but strongly inhibit androgen-independent proliferation. Moreover, in our experience, these therapeutic concentrations induce changes in cell morphology associated with an increase in the expression of molecules, which are crucial for the maintenance of a differentiated phenotype. These results indicate that VA influences cancer cytoarchitecture and behaviour and, in particular, may render hormone-refractory tumors less aggressive.

\section{Acknowledgements}

This study was partly supported by grants from the Catholic University of the Sacred Heart (Fondi di Ateneo 2004 and 2005).

\section{References}

1. Johnstone RW: Histone-deacetylase inhibitors: novel drugs for the treatment of cancer. Nat Rev Drug Discov 1: 287-299, 2002.

2. Acharya MR, Sparreboom A, Venitz J and Figg WD: Rational development of histone deacetylase inhibitors as anticancer agents: a review. Mol Pharmacol 68: 917-932, 2005.

3. Thiagalingam S, Cheng KH, Lee HJ, Mineva N, Thiagalingam A and Ponte JF: Histone deacetylases: unique players in shaping the epigenetic histone code. Ann NY Acad Sci 983: 84-100, 2003.

4. Roth SY and Allis CD: Histone acetylation and chromatin assembly: a single escort, multiple dances? Cell 87: 5-8, 1996.

5. Guan M, Zhou X, Soulitzis N, Spandidos DA and Popescu NC: Aberrant methylation and deacetylation of deleted in liver cancer-1 gene in prostate cancer: potential clinical applications. Clin Cancer Res 12: 1412-1419, 2006.

6. Phiel CJ, Zhang F, Huang EY, Guenther MG, Lazar MA and Klein PS: Histone deacetylase is a direct target of valproic acid, a potent anticonvulsant, mood stabilizer, and teratogen. J Biol Chem 276: 36734-36741, 2001.

7. Gottlicher M, Minucci S, Zhu P, Kramer OH, Schimpf A, Giavara S, Sleeman JP, Lo Coco F, Nervi C, Pelicci PG and Heinzel T: Valproic acid defines a novel class of HDAC inhibitors inducing differentiation of transformed cells. EMBO J 20: 6969-6978, 2001.

8. Gottlicher M: Valproic acid: an old drug newly discovered as inhibitor of histone deacetylases. Ann Hematol 83: S91-S92, 2004.

9. Kuendgen A, Schmid M, Schlenk R, Knipp S, Hildebrandt B, Steidl C, Germing U, Haas R, Dohner H and Gattermann N: The histone deacetylase (HDAC) inhibitor valproic acid as monotherapy or in combination with all-trans retinoic acid in patients with acute myeloid leukemia. Cancer 106: 112-119, 2006.

10. Kuendgen A and Gattermann N: Valproic acid for the treatment of myeloid malignancies. Cancer 110: 943-954, 2007.

11. Blaheta RA and Cinatl J Jr : Anti-tumor mechanisms of valproate: a novel role for an old drug. Med Res Rev 22: 492-511, 2002.

12. Milutinovic S, D'Alessio AC, Detich N and Szyf M: Valproate induces widespread epigenetic reprogramming which involves demethylation of specific genes. Carcinogenesis 28: 560-571, 2007.

13. Bosetti F, Bell JM and Manickam P: Microarray analysis of rat brain gene expression after chronic administration of sodium valproate. Brain Res Bull 65: 331-338, 2005.

14. Graziani G, Tentori L, Portarena I, Vergati M and Navarra P: Valproic acid increases the stimulatory effect of estrogens on proliferation of human endometrial adenocarcinoma cells. Endocrinology 144: 2822-2828, 2003.

15. Takai N, Desmond JC, Kumagai T, Gui D, Said JW, Whittaker S, Miyakawa I and Koeffler HP: Histone deacetylase inhibitors have a profound antigrowth activity in endometrial cancer cells. Clin Cancer Res 10: 1141-1149, 2004.

16. Mongan NP and Gudas LJ: Valproic acid, in combination with all-trans retinoic acid and 5-aza-2'-deoxycytidine, restores expression of silenced RARbeta2 in breast cancer cells. Mol Cancer Ther 4: 477-486, 2005.
17. Thelen P, Schweyer S, Hemmerlein B, Wuttke W, Seseke F and Ringert RH: Expressional changes after histone deacetylase inhibition by valproic acid in LNCaP human prostate cancer cells. Int J Oncol 24: 25-31, 2004.

18. Angelucci A, Valentini A, Millimaggi D, Gravina GL, Miano R, Dolo V, Vicentini C, Bologna M, Federici G and Bernardini S: Valproic acid induces apoptosis in prostate carcinoma cell lines by activation of multiple death pathways. Anticancer Drugs 17: 1141-1150, 2006.

19. Leader JE, Wang C, Fu M and Pestell RG: Epigenetic regulation of nuclear steroid receptors. Biochem Pharmacol 72: 1589-1596, 2006.

20. Chmelar R, Buchanan G, Need EF, Tilley W and Greenberg NM: Androgen receptor coregulators and their involvement in the development and progression of prostate cancer. Int J Cancer 120: 719-733, 2007.

21. Fu M, Rao M, Wang C, Sakamaki T, Wang J, Di Vizio D, Zhang X, Albanese C, Balk S, Chang C, Fan S, Rosen E, Palvimo JJ, Janne OA, Muratoglu S, Avantaggiati ML and Pestell RG: Acetylation of androgen receptor enhances coactivator binding and promotes prostate cancer cell growth. Mol Cell Biol 23: 8563-8575, 2003.

22. Fu M, Wang C, Zhang X and Pestell RG: Acetylation of nuclear receptors in cellular growth and apoptosis. Biochem Pharmacol 68: 1199-1208, 2004.

23. Gaughan L, Logan IR, Cook S, Neal DE and Robson CN: Tip60 and histone deacetylase 1 regulate androgen receptor activity through changes to the acetylation status of the receptor. J Biol Chem 277: 25904-25913, 2002.

24. Korkmaz CG, Fronsdal K, Zhang Y, Lorenzo PI and Saatcioglu F: Potentiation of androgen receptor transcriptional activity by inhibition of histone deacetylation-rescue of transcriptionally compromised mutants. J Endocrinol 182: 377-389, 2004.

25. Sica G, Dell'Acqua G, Iacopino F, Fattorossi A, Marchetti P, van der Kwast TH and Pavone-Macaluso M: Androgen receptors and hormone sensitivity of a human prostatic cancer cell line (PC-3) are modulated by natural beta-interferon. Urol Res 22: 33-38, 1994.

26. Foty RA and Steinberg MS: Cadherin-mediated cell-cell adhesion and tissue segregation in relation to malignancy. Int J Dev Biol 48: 397-409, 2004.

27. Verras M and Sun Z: Roles and regulation of Wnt signaling and beta-catenin in prostate cancer. Cancer Lett 237: 22-32, 2006.

28. Jennbacken K, Gustavsson H, Welen K, Vallbo C and Damber JE: Prostate cancer progression into androgen independency is associated with alterations in cell adhesion and invasivity. Prostate 66: 1631-1640, 2006.

29. Peterson GL: A simplification of the protein assay method of Lowry et al which is more generally applicable. Anal Biochem 83: 346-356, 1977.

30. Angelucci C, Iacopino F, Lama G, Capucci S, Zelano G, Boca M, Pistilli A and Sica G: Apoptosis-related gene expression affected by a GnRH analogue without induction of programmed cell death in LNCaP cells. Anticancer Res 24: 2729-2738, 2004.

31. Liu AY: Differential expression of cell surface molecules in prostate cancer cells. Cancer Res 60: 3429-3434, 2000.

32. Annicotte JS, Iankova I, Miard S, Fritz V, Sarruf D, Abella A, Berthe ML, Noel D, Pillon A, Iborra F, Dubus P, Maudelonde T, Culine $S$ and Fajas L: Peroxisome proliferator-activated receptor gamma regulates E-cadherin expression and inhibits growth and invasion of prostate cancer. Mol Cell Biol 26: 7561-7574, 2006.

33. Abdul $\mathrm{M}$ and Hoosein $\mathrm{N}$ : Inhibition by anticonvulsants of prostate-specific antigen and interleukin- 6 secretion by human prostate cancer cells. Anticancer Res 21: 2045-2048, 2001.

34. Maier S, Reich E, Martin R, Bachem M, Altug V, Hautmann RE and Gschwend JE: Tributyrin induces differentiation, growth arrest and apoptosis in androgen-sensitive and androgen-resistant human prostate cancer cell lines. Int J Cancer 88: 245-251, 2000.

35. Fronsdal K and Saatcioglu F: Histone deacetylase inhibitors differentially mediate apoptosis in prostate cancer cells. Prostate 62: 299-306, 2005.

36. Xia Q, Sung J, Chowdhury W, Chen CL, Hoti N, Shabbeer S, Carducci M and Rodriguez R: Chronic administration of valproic acid inhibits prostate cancer cell growth in vitro and in vivo. Cancer Res 66: 7237-7244, 2006.

37. Buchanan G, Craft PS, Yang M, Cheong A, Prescott J, Jia L, Coetzee GA and Tilley WD: PC-3 cells with enhanced androgen receptor signaling: a model for clonal selection in prostate cancer. Prostate 60: 352-366, 2004. 
38. Alimirah F, Chen J, Basrawala Z, Xin H and Choubey D: DU-145 and PC-3 human prostate cancer cell lines express androgen receptor: implications for the androgen receptor functions and regulation. FEBS Lett 580: 2294-2300, 2006.

39. Sun C, Shi Y, Xu LL, Nageswararao C, Davis LD, Segawa T, Dobi A, McLeod DG and Srivastava S: Androgen receptor mutation (T877A) promotes prostate cancer cell growth and cell survival. Oncogene 25: 3905-3913, 2006.

40. Yeap BB, Krueger RG and Leedman PJ: Differential posttranscriptional regulation of androgen receptor gene expression by androgen in prostate and breast cancer cells. Endocrinology 140: 3282-3291, 1999.

41. Veldscholte J, Berrevoets CA and Mulder E: Studies on the human prostatic cancer cell line LNCaP. J Steroid Biochem Mol Biol 49: 341-346, 1994.

42. Halkidou K, Cook S, Leung HY, Neal DE and Robson CN: Nuclear accumulation of histone deacetylase 4 (HDAC4) coincides with the loss of androgen sensitivity in hormone refractory cancer of the prostate. Eur Urol 45: 382-389, 2004

43. Death AK, McGrath KC and Handelsman DJ: Valproate is an anti-androgen and anti-progestin. Steroids 70: 946-953, 2005.

44. Valentini A, Biancolella M, Amati F, Gravina P, Miano R, Chillemi G, Farcomeni A, Bueno S, Vespasiani G, Desideri A, Federici G, Novelli $G$ and Bernardini S: Valproic acid induces neuroendocrine differentiation and UGT2B7 up-regulation in human prostate carcinoma cell line. Drug Metab Dispos 35: 968-972, 2007.

45. Bordin M, D'Atri F, Guillemot L and Citi S: Histone deacetylase inhibitors up-regulate the expression of tight junction proteins. Mol Cancer Res 2: 692-701, 2004.
46. Nelson EC, Cambio AJ, Yang JC, Ok JH, Lara PN Jr and Evans CP: Clinical implications of neuroendocrine differentiation in prostate cancer. Prostate Cancer Prostatic Dis 10: 6-14, 2007.

47. Wright ME, Tsai MJ and Aebersold R: Androgen receptor represses the neuroendocrine transdifferentiation process in prostate cancer cells. Mol Endocrinol 17: 1726-1737, 2003.

48. Floryk D and Huberman E: Differentiation of androgenindependent prostate cancer PC-3 cells is associated with increased nuclear factor-kappaB activity. Cancer Res 65: 11588-11596, 2005.

49. Litvinov IV, Vander Griend DJ, Xu Y, Antony L, Dalrymple SL and Isaacs JT: Low-calcium serum-free defined medium selects for growth of normal prostatic epithelial stem cells. Cancer Res 66: 8598-8607, 2006.

50. Huang H, Reed CP, Zhang JS, Shridhar V, Wang L and Smith DI: Carboxypeptidase A3 (CPA3): a novel gene highly induced by histone deacetylase inhibitors during differentiation of prostate epithelial cancer cells. Cancer Res 59: 2981-2988, 1999.

51. Angelucci C, Iacopino F, Ferracuti S, Urbano R and Sica G: Recombinant human interferon- $\beta$ affects androgen receptor level, neuroendocrine differentiation, cell adhesion and motility in prostate cancer cells. J Interferon Cytokine Res 27: 643-652, 2007.

52. Yuan TC, Veeramani S and Lin MF: Neuroendocrine-like prostate cancer cells: neuroendocrine transdifferentiation of prostate adenocarcinoma cells. Endocr Relat Cancer 14: 531-547, 2007. 